解説

\title{
アルミニウム合金粉末のレーザ樍層造形に伴う組織形成の理解に向けて
}

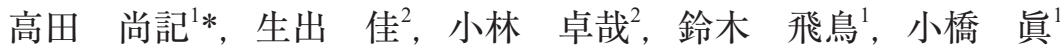 \\ ${ }^{1}$ 名古屋大学大学院工学研究科物質プロセス工学専攻, $\bar{T}$ 464-8603 名古屋市千種区不老町 1. \\ 2 (株)メカニカルデザイン, $\bar{T}$ 182-0024 東京都調布市布田 1-40-2 アクシス調布 2 階.
}

\section{Toward Understanding the Mechanism behind Microstructure Development of Aluminum Alloy Powders Additively Manufactured by Selective Laser Melting}

\author{
Naoki TAKATA $^{1 *}$, Kai OIDE ${ }^{2}$, Takaya KOBAYASHI ${ }^{2}$, Asuka SUZUKI ${ }^{1}$ and Makoto KOBASHI \\ ${ }^{1}$ Department of Materials Process Engineering, Graduate School of Engineering, Nagoya University, Furo-cho, Chikusa-ku, Nagoya 464-8603, Japan. \\ ${ }^{2}$ Mechanical Design \& Analysis Corporation, AXIS Chofu 2F, 1-40-2 Fuda, Chofu, Tokyo 182-0024, Japan.
}

Received July 17, 2019; Revised July 31, 2019; Accepted August 29, 2019

\begin{abstract}
The present article describes a possible mechanism behind the microstructure development in aluminum (Al) alloy (AlSi10Mg: Al-10wt $\% \mathrm{Si}-0.3 \mathrm{wt} \% \mathrm{Mg}$ ) parts additively manufactured by selective laser melting (SLM) combined with powder bed system (one of the most conventional additive manufacturing processes for metals). It introduces the thermodynamic calculation applied to the studied alloy to understand the microstructure development during the SLM process and then elaborates microstructural features of SLM-fabricated Al alloy parts characterized by electron microscopy and electron back-scattered diffraction analyses. The aforementioned results are utilized to present the formation process of microstructure through the rapid solidification during the SLM process. An attempt was made to quantify the cooling rate and molten pool dimensions using the preliminary two-dimensional finite element model. The analyzed thermal gradient and cooling rates are presented as well.
\end{abstract}

\section{KEY WORDS}

additive manufacturing, aluminum alloys, rapid solidification, thermodynamic calculation, finite element model

\section{1 はじめに}

近年，従来の粉末治金積層造形 (Additive Manufacturing) 技術に関する研究開発が盛んである ${ }^{1-6)}$. 本技術は従来の加工 法では不可能な三次元複雑形状の造形を可能とするため, 構 造体の軽量化等に極めて有用である．積層造形技術を用いて 金属材料を造形する装置を一般に金属 3D プリンタと呼ぶ場 合が多い。これらの技術の中で最も一般的なものは，粉末床 溶融結合（Powder Bed Fusion: PBF）技術を基礎としたレー ザ積層造形や電子ビーム積層造形であるが, 大型部材の造形 には指向性エネルギー堆積 (Direct Energy Deposition: DED) 法 ${ }^{3)}$ (簡略化されてデポジション法と呼ばれる場合が多い) なども適用されている.

我々は，多孔質金属（ポーラス金属）構造体を作製するプ ロセス技術としてレーザ積層造形技術に着目している。特に

* Corresponding author, E-mail: takata.naoki@material.nagoya-u.ac.jp
アルミニウムは軽量かつ高い比強度を有するため, ポーラス アルミニウムは超軽量かつ高い比剛性を有し, 遮音・吸音 性, 制振性, 断熱性等に優れるなどの物性を示す。また, ポーラス金属は圧壊時の変形に伴って高エネルギー吸収性を 示す ${ }^{7)}$ ため, 自動車などの輸送機器の衝撃吸収材として適用 が期待される。このポーラスアルミニウムのエネルギー吸収 能の向上及び安定化を実現するには，気孔形態の均質・微細 化やこれらの制御による圧縮強度（プラトー応力）の安定化 が必要となる。ポーラスアルミニウムの気孔形態の精緻な制 御を実現するプロセスとして，レーザ積層造形技術が有用で ある。レーザ積層造形技術で最も汎用的なプロセスのひとつ である選択的レーザ溶融（Selective Laser Melting: SLM）は 原料の金属粉末を 1 層ずつ積層し，造形部にレーザ照射し溶 融・凝固を繰り返しながら三次元の金属構造体を造形する加 工法である ${ }^{1-4)}$ ．近年，金属アルミニウムのレーザ反射率を低 減するため低波長レーザの $\mathrm{Yb}$ ファイバレーザを搭載した積 
層造形装置が開発され，アルミニウム金属粉末の造形が可能 となった，近年，JIS 規格 ADC3（アルミニウム合金ダイキャ スト）相当の組成を有する AlSi10Mg 合金 ${ }^{8}$ や高強度合金を 用いた造形体の研究開発が飛躍的な進歩を遂げている 近年，規則的な気孔形態を有するポーラス構造のひとつであ るラティス構造体が注目され，積層造形により作製されたラ ティス構造体の圧縮特性 ${ }^{11,12)}$ やその応力分布解析 ${ }^{12,13}$, 圧縮

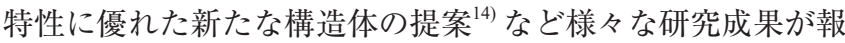
告されている，我々はレーザ積層造形技術のひとつである SLM 法を用いて造形されたアルミニウム合金（AlSi10Mg 合 金）とそのポーラス構造体の組織と力学特性の理解を目指 し，アルミニウム合金造形体の組織占) とその熱処理に伴う変 化 $^{16)}$, 複雑形状造形体の組織の特徵 ${ }^{17-19)}$ などを解明してきた。 現在，それらの理解を基にポーラス構造体の力学特性とその 制御に関して検討している.

本解説では, 熱力学計算を基に作成した $\mathrm{Al}$ 系多元系状態 図を基にしてアルミニウム合金（AlSi10Mg 合金）造形体の 組織の特異性を詳細に調查した結果 $\left.{ }^{15}\right)$ を紹介する。また，実 験による測定が極めて困難であるレーザ積層造形中の温度分 布・履歴を予測するため, 有限要素モデルを用いた熱伝導解 析結果とその解析に基づいた造形体の特徴的な組織の再現法 を紹介する。これらの結果を基に，アルミニウム合金粉末の レーザ積層造形に伴う組織形成の現状の理解を述べる。

\section{2 熱力学計算を基にした凝固に伴う組織形成の予測}

本研究で用いた積層造形の原料は，ガスアトマイズ球状 $\mathrm{AlSi10Mg}$ 合金粉末である ${ }^{15,16)}$. 本合金粉末の粒子径分布とそ の粉末形状を示した走查電子顕微鏡（SEM）像を，Fig. 1 に 示す. 合金粉末の粒子径は数 $\mu \mathrm{m}$ から $100 \mu \mathrm{m}$ 以上の分布を 有するが，測定された平均粒子径は $29 \mu \mathrm{m}$ であった（Fig. 1 $(a, b))$ 。また，粉末粒子は粒子径に依らず球状形態を有す る (Fig. 1 (c))，誘導結合プラズマ発光分光を用いて合金粉 末の組成を分析した結果，その合金組成は Al-10.7 $\mathrm{Si}-0.2 \mathrm{Mg}$ $0.4 \mathrm{Fe}(\mathrm{mass} \%)$ であった ${ }^{15,16)}$ ．合金粉末及び造形体の組成分 析を行った結果，ほぼ同じ合金組成であった。この結果は, SLM 法のレーザ局所溶融による合金成分の変化はほとんど ないことを示す，本研究では AlSi10Mg 合金粉末のレーザ局 所溶融による組織形成を予測するため, 現用の熱力学デー夕 ベース ${ }^{20)}$ を基に本合金の構成相及び構成相の組成変化を計算 した，組成分析結果に基づき，本研究では AlSi10Mg 合金組 成を $\mathrm{Al}-\mathrm{Si}-\mathrm{Mg}-\mathrm{Fe} 4$ 元系とみなした。熱力学計算によって作 成された $\mathrm{Al}-\mathrm{Si}-\mathrm{Mg}-\mathrm{Fe} 4$ 元系の $\mathrm{Al}-0.2 \mathrm{Mg}-0.4 \mathrm{Fe}$ (mass\%) 組 成に扔ける断面図上に示した AlSi10Mg 合金の組成を，Fig. 2 (a)に示す，本合金は約 $600^{\circ} \mathrm{C}$ に打いて液相線を有し，初晶 $\alpha-\mathrm{Al}$ （fcc）相の生成を伴って凝固する。温度の低下に伴っ て, 約 $540^{\circ} \mathrm{C}$ の固相線以下で $\alpha-\mathrm{Al}$ 相, $\mathrm{Si}$ 相 (diamond 構造) 及び $\beta-\mathrm{AlFeSi}$ 相（ $\tau_{6}-\mathrm{Al}_{9} \mathrm{Fe}_{2} \mathrm{Si}_{2}$ 相）の 3 相領域に遷移する。本 合金の鋳造材（冷却速度 $10^{-1}{ }^{\circ} \mathrm{C} / \mathrm{s}$ ）は微細な $\mathrm{Si}$ 相及び $\mathrm{Fe}$ を 含む金属間化合物相に取り囲まれた初晶 $\alpha-\mathrm{Al}$ を持つ組織形 態を有することが報告され，本計算状態図の相領域の変化
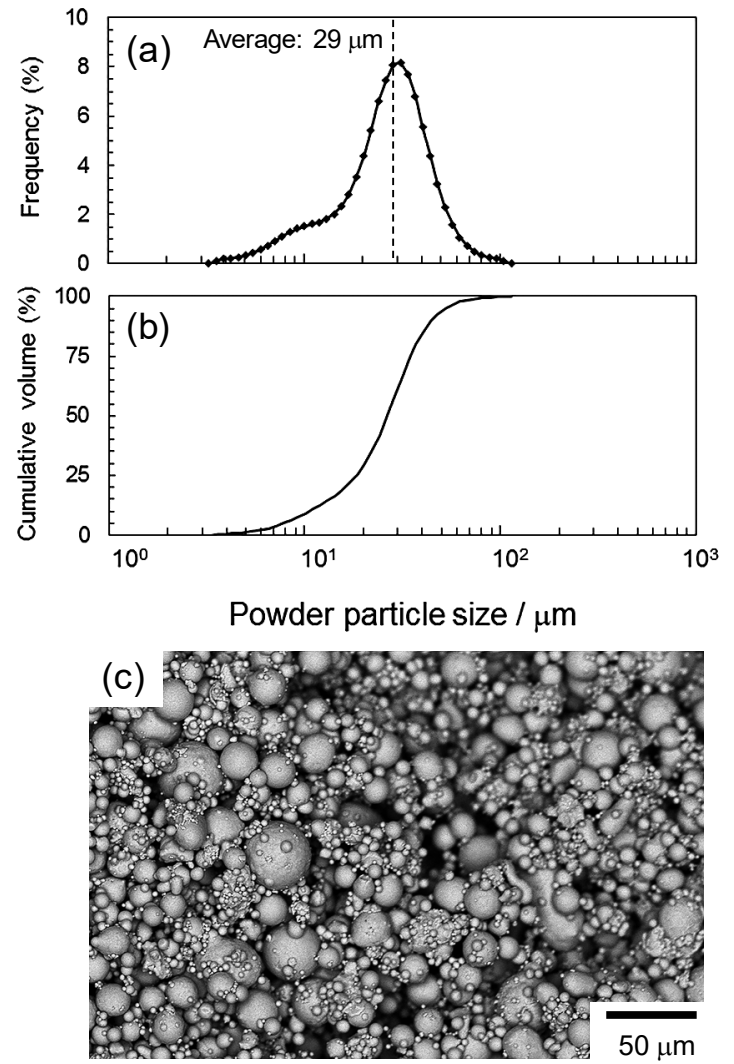

Fig. 1 (a, b) Particle size distribution and (c) SEM image of AlSi10Mg alloy powder studied.

と良く対応する。なお，本組成は $400^{\circ} \mathrm{C}$ 以下において $\mathrm{Mg}_{2} \mathrm{Si}$ 相を含む 4 相域が存在するが, $\mathrm{Mg}_{2} \mathrm{Si}$ 相のモル分率は約 $0.2 \%$ と他の構成相に比べて非常に低い，したがって，本合金の 時效硬化能は, 従来の Al- $\mathrm{Mg}-\mathrm{Si}$ 合金と比較して低い ${ }^{21)}$ 。ま た Fig. 1 (b, c) に, Scheilの条件 ${ }^{22}$ における AlMg10Si 合金の 固相率の増加（凝固）に伴う構成相の変化と液相の組成の変 化を示す．Scheil の条件は，液相は完全混合（十分に原子拡 散可能)，固相拡散は起こらず，固相／液相界面に局所平衡 が成り立つものである。凝固中の固相拡散を無視した本条 件は，急冷凝固の条件に近いと考えられる。本条件下に拉 いて $555 \sim 590^{\circ} \mathrm{C}$ 温度範囲にて液相から種々の固相が生成す ると予測される（Fig. 2 (b))。 また，液相の組成は固相率が 9 割以上の増加後に著しく変化し, 特に $\mathrm{Mg}$ 濃度が増加する (Fig. 2 (c))。これは, 本合金の最終凝固部 $(\alpha / \mathrm{Si}$ 共晶部もし くは $\alpha / \mathrm{Si} / \beta$ 共晶部）に $\mathrm{Mg}$ 元素が濃化することを予測する.

\section{AlSi10Mg 合金造形体の組織解析}

本研究では，(株)EOS製・金属粉末積層造形装置（EOSINT M 280) を用いて造形された AlSi10Mg 合金試料（45 mm の 立方体形状）の組織を解析した結果を示す。アルキメデス法 により測定した本造形体の相対密度は $99 \%$ 以上であり，レー ザ出力・走查条件は最適化されたものである．粉末積層方向 に対して平行な方向 $(\mathrm{Z}$ 方向 $)$ 及び垂直な方向 $(\mathrm{X} / \mathrm{Y}$ 方向 $)$ から観察した AlSi10Mg 合金造形体の組織 ${ }^{15)}$ を Fig. 3 に示す. 造形方法（Z方向）から観察された光学顕微鏡像は, レー 

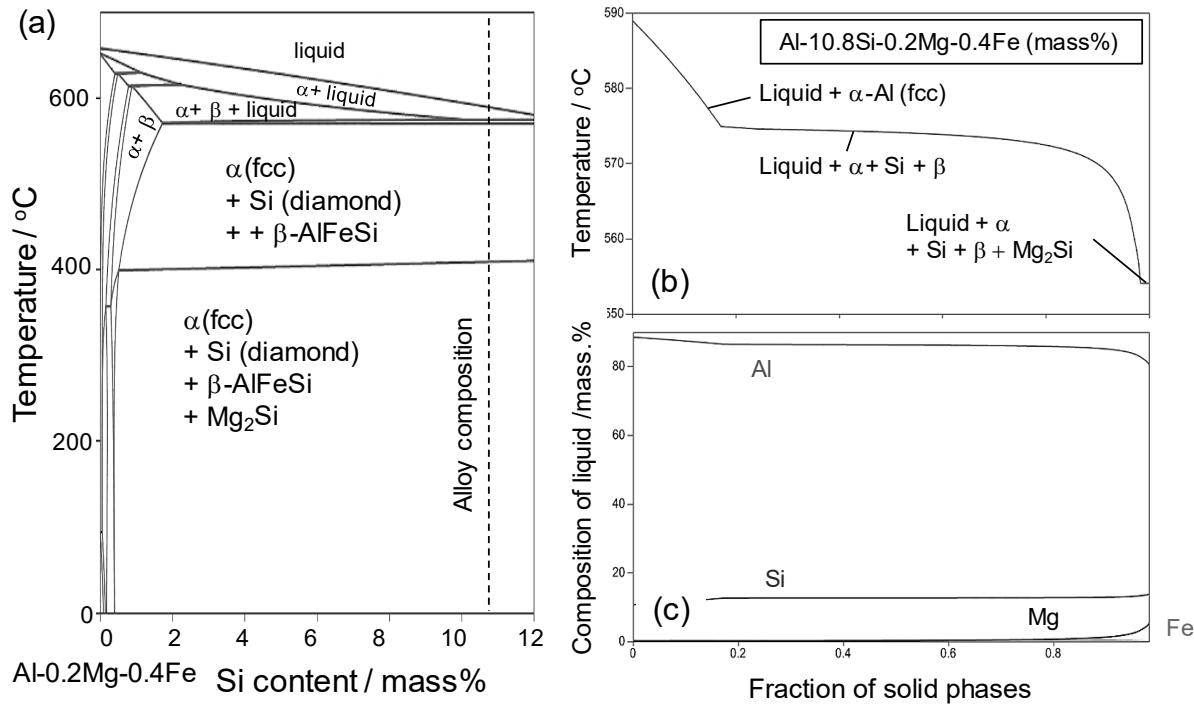

Fig. 2 (a) Calculated vertical section ( $\mathrm{Al}-0.2 \mathrm{Mg}-0.4 \mathrm{Fe}-\mathrm{xSi}$ ) of the $\mathrm{Al}-\mathrm{Si}-\mathrm{Mg}-\mathrm{Fe}$ quaternary system ${ }^{15)}$, (b, c) calculated Scheil solidification sequence for AlSi10Mg alloy studied ${ }^{15)}$ : (b) solid phases at various temperatures, (c) component partitioning in liquid phase.
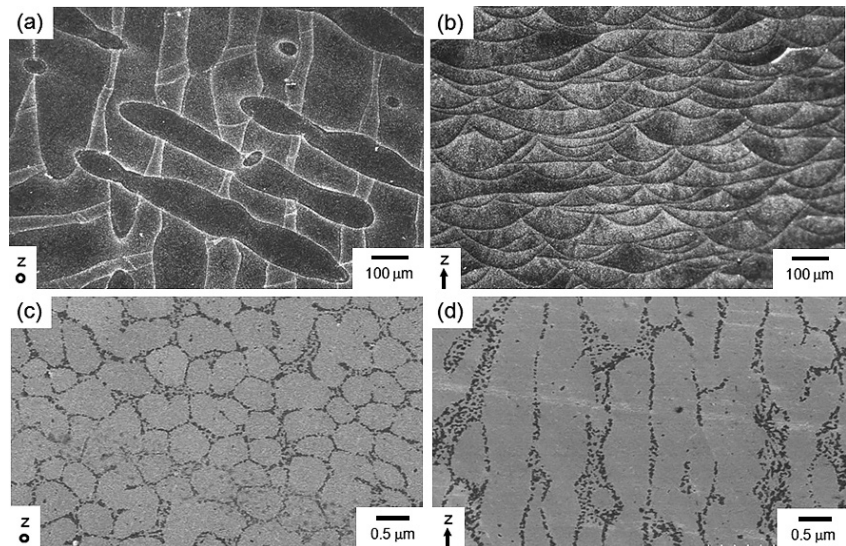

Fig. 3 (a, b) Optical micrographs, (c, d) SEM images showing microstructure of the AlSi10Mg alloy fabricated by selective laser melting of power bed metal, which were observed from $(\mathrm{a}, \mathrm{c}) \mathrm{z}$ direction and $(\mathrm{b}$ d) normal to $\mathrm{z}$ direction ${ }^{15)}$.

ザ走査パターンに起因する幅 100〜200 $\mu \mathrm{m}$ の帯状組織を示 す (Fig. 3 (a))。また, $\mathrm{X} / \mathrm{Y}$ 方向から観察される組織は, 数 $100 \mu \mathrm{m}$ の幅を持つ複数の円弧から構成される鱗状形態を呈 する (Fig. 3 (b))。これらの組織形態は，レーザ局所加熱によ り積層粉末及び造形体が溶融・凝固した溶融池（melt pool） に対応する。その鱗状形態を持つ組織内部では, 幅 $1 \mu \mathrm{m}$ 以 下の伸長した $\alpha$ 相（明るいコントラスト）を粒子径 $100 \mathrm{~nm}$ 以下の $\mathrm{Si}$ 粒子（暗いコントラスト）に囲まれている微細 組織（Fig. 3 (c, d)）がSEMにて観察される。これは， $\alpha / \mathrm{Si}$ 共晶組織に囲まれた初晶 $\alpha$ 相に対応する。また，溶融池の中 央部に抒ける初晶 $\alpha$ 相は柱状形態であり, 造形方向に伸長す ることがわかる. Fig. 4 に，溶融池境界部近傍の組織（粉末 積層方向と平行な方向から観察したもの）の SEM 像 ${ }^{15)}$ を示 す. 溶融池内部の初晶 $\alpha$ 相は円弧状溶融池の中心部に向かっ て伸長する。この組織形態は，レーザ局所溶融後，照射部へ 向かって凝固が進行することを示す，溶融池境界部近傍の $\alpha$
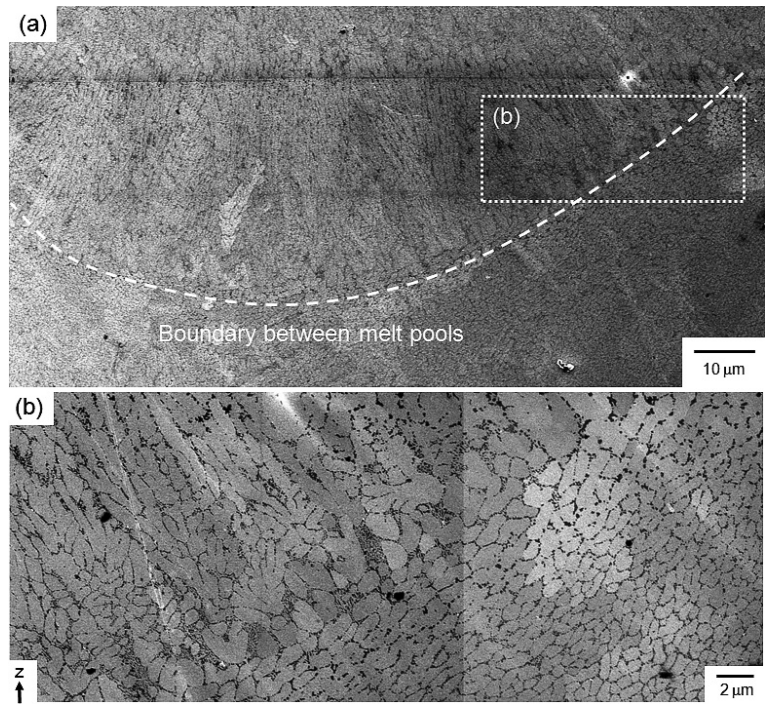

Fig. 4 (a) SEM image showing microstructure in the vicinity of the boundary between melt pools in the AlSi10Mg alloy fabricated, (b) highmagnification image corresponding to the region (b) in Fig. 3 (a) ${ }^{15)}$.

相は等軸粒形態を有する (Fig. 4 (b))。溶融池内部と比較し て微細な組織形態は, 境界近傍における局所的に高い冷却速 度を示唆する。

AlSi10Mg 合金造形体の電子線後方散乱回折（Electron BackScattered Diffraction: EBSD) を用いた結晶方位解析結果を Fig. 5 に示す。太線で示す大角粒界（方位差 $15^{\circ}$ 以上）に囲まれた 結晶粒は円弧状形態の溶融池内部において放射状に伸長する (Fig. 5 (a))。また, EBSD 解析により得られた単位面積当たり の大角粒界の総長さを用いて評価される大角粒界の平均間隔 （結晶粒界分布がランダムと仮定した場合）は約 $8 \mu \mathrm{m}$ である. これは造形体の結晶粒径に相当し, 従来の鋳造アルミニウム 合金の結晶粒径（数 $10 \mu \mathrm{m}$ 数 $100 \mu \mathrm{m} ）$ と比べて著しく小さい. これは, レーザ局所溶融後の急速冷却による凝固組織形成に 起因すると考えられる．また，本造形体は，造形方向に対し 

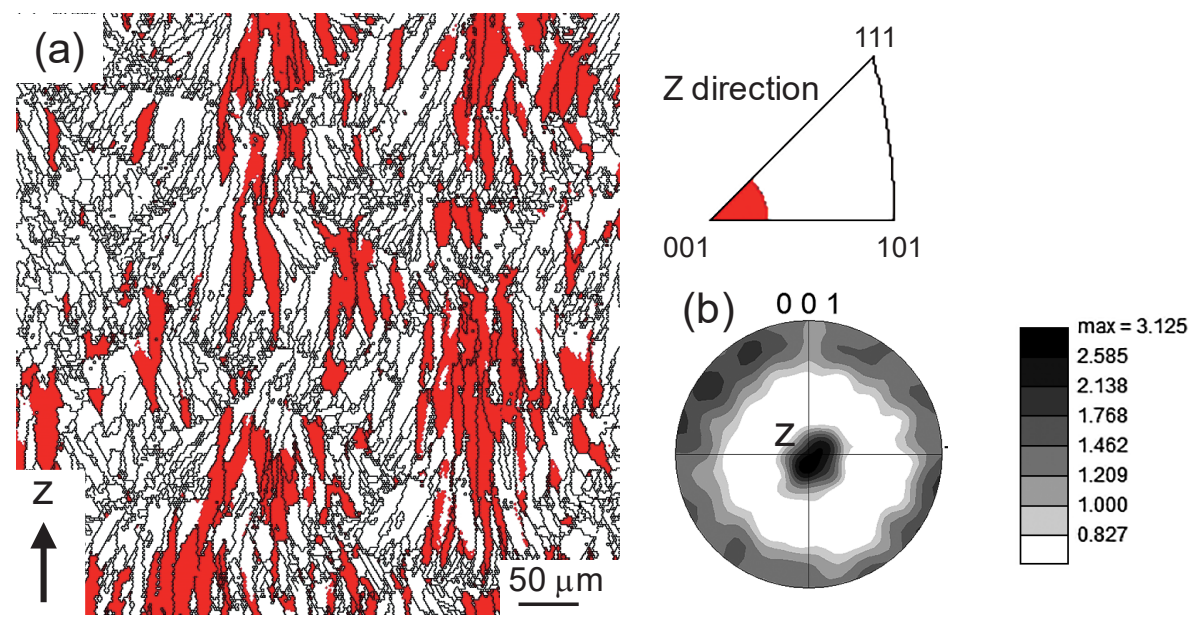

Fig. 5 (a) Distribution map for $<001>$-oriented grains and (b) 001 pole figure of the $\alpha$-Al matrix in the selectively laser melted AlSi10Mg alloy. The redcolored region presents the $<001>$ orientation parallel to the building direction ( $\mathrm{z}$ direction) according to a unit triangle indicating a tolerance of misorientation $\left(15^{\circ}\right)^{15}$.
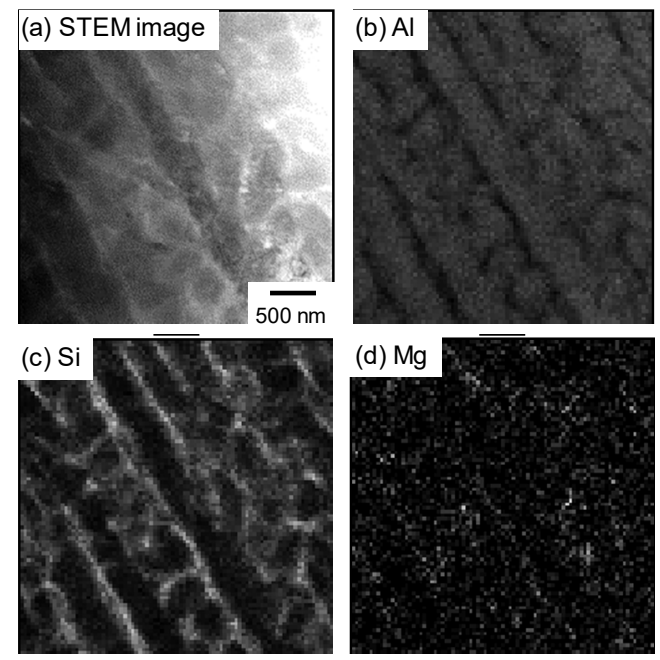

Fig. 6 (a) STEM image showing microstructure of the AlSi10Mg alloy fabricated and (b-d) corresponding EDS element maps of (b) Al, (c) $\mathrm{Si}$ and (d) $\mathrm{Mg}$

て比較的強い $\{100\}$ 集合組織を有する (Fig. 5 (b))。試料内部 の約 2 割の結晶粒が造形方向（Z方向）に<100>方向を持つ (<001>//Z 方向から $15^{\circ}$ の誤差を許容した方位を赤色で示した 図を Fig. 5 (a) に示す)， <100>方位を持つ結晶粒の多くは溶融 池 (円弧状組織) の中央でZ方向に伸長する傾向が認められる. これらの特徵は同じ $\mathrm{fcc}$ 構造を有する $\mathrm{Ni}$ 合金衫でも観察され， $\alpha$ 相（fcc 構造）における $<001>$ 優先成長方位に対応する.

Fig. 6 に, AlSi10Mg 合金造形体の走查透過電子顕微鏡 (Scanning Transmission Electron Microscope: STEM) 像とエネ ルギー分散型 X線分光法による元素分析結果を示す。伸張 した $\alpha$ 相内部に明瞭な析出相は観察されない（Fig. 6 (a)). また，エネルギー分散型 X線分光による元素分析は， $\alpha$ 母相 内に合金元素であるSi は数\%検出されるが，他の合金元素 が濃化した相は観察されなかった（Fig. 6(b-d))。これは，造 形体内部の $\alpha$ 相は合金元素（特に Si 元素）を過飽和に含ん だ固溶体であることを示す．3次元アトムプローブを用いた

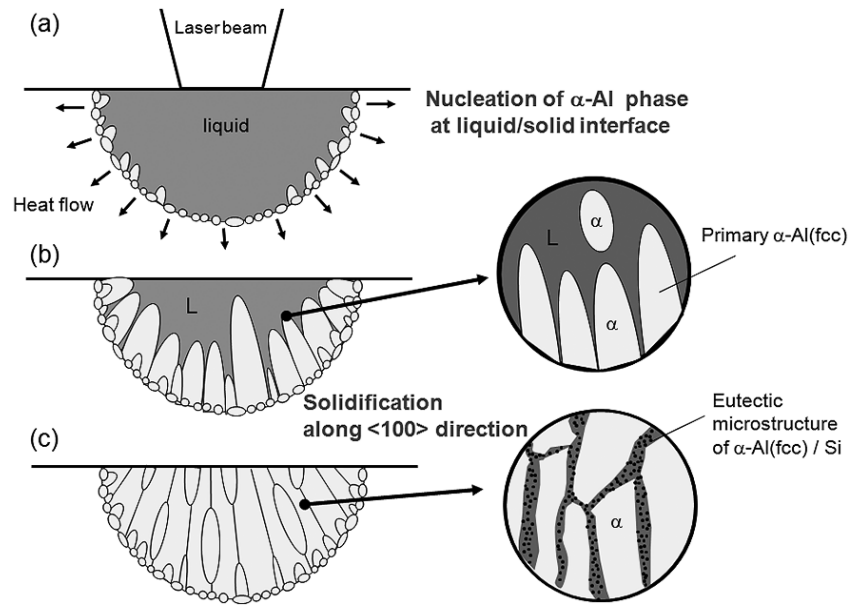

Fig. 7 Schematics showing the formation process of microstructure in the AlSi10Mg alloy during the selective laser melting process: (a) local melting by laser-beam irradiation, (b) $\alpha$-Al grains solidifying along the preferential $<100>$ direction, (c) formation of columnar $\alpha-\mathrm{Al}$ grains surrounded by fine eutectic Si particles ${ }^{15}$.

元素分析 ${ }^{24}$ は $\alpha$ 相内に合金元素 $(\mathrm{Si}$ 及び $\mathrm{Mg})$ のクラスター 形成を示唆しており， $\alpha$ 相の過飽和固溶体の詳細な解析が今 後必要である。なお， $\alpha / \mathrm{Si}$ 共晶部に濃化した $\mathrm{Mg}$ 元素が検出 された (Fig. 6 (d))。これは, Scheil の凝固シミュレーション の結果（Fig. 2(c)）と良く一致する.

本組織観察結果を基に，レーザ積層造形に伴う AlSi10Mg 合金の組織形成過程の模式図 ${ }^{15)}$ を Fig. 7 に示す。一点のレー ザ照射による局所加熱を想定すると造形体（積層合金粉末） 内部に 3 次元的に半球状の溶融領域が形成する (Fig. 7 (a)). 最も冷却速度の速い固液界面近傍に扔いて, 微細な $\alpha$ 相が生 成する，その後，放射状の放熱方向に対して逆方向に凝固は 進行する。したがって, 初晶 $\alpha$ 相がレーザ照射中心部（最も 高温な領域）に向かって成長する（Fig.7 (b))。 その際, 固 液界面に打いて初晶 $\alpha$ 相は $\mathrm{Si}$ の濃化した低融点の液相に囲 まれ，その液相は温度低下に伴い $\alpha$ 相と $\mathrm{Si}$ 相に共晶分解す る。の結果, 微細な $\alpha / \mathrm{Si}$ 共晶組織に囲まれた柱状の $\alpha$ 相か 
ら構成される組織形態が形成する（Fig. 7 (c))。造形体の組 織はレーザ局所溶融後の急速冷却に起因する非平衡状態であ るため，合金元素は $\alpha$ 相に過飽和に固溶すると考えられる.

\section{4 有限要素モデルを用いたレーザ樍層造形中の 温度履歴の解析}

以上の熱力学計算及び造形体の組織解析は，レーザ積層造 形に伴うアルミニウム合金の組織形成が，レーザ局所溶融後 の急速冷却に伴う凝固組織を基に理解できることを示した.

これは，アルミニウム合金造形体の組織が積層造形中の温度 履歷，特にレーザ局所加熱後の泠却速度を用いて制御できる ことを示す。これまで多くの研究者が積層造形プロセスを模 擬したレーザ照射による粉末層の構造変化のその場観察 ${ }^{25}$ を 試みてきたが，実験的に測定された温度の報告は極めて少 ない26). 本研究では, 有限要素モデルの熱伝導解析を用いて レーザ照射による合金粉末層と造形体の温度履歴の評価を 行った．本来，積層造形プロセスは粉末層上に照射したレー ザの走查であるため 3 次元有限要素モデルを用いた解析を行 う必要がある。本研究ではレーザ照射による局所加熱と冷却 の温度履歴に焦点を絞り，2 次元モデルの熱伝導解析を行っ た．本解析で使用した 2 次元モデルを Fig. 8 (a) に示す．本モ デルは約 $1 \mathrm{~mm}$ のベースプレート（アルミニウム合金製）の 上に厚さ $30 \mu \mathrm{m}$ の合金粉末層を積層した構造である。なお， 本モデルの奥行き厚さは $0.1 \mathrm{~mm}$ とした. 4節点熱伝導要素 を適用し，要素数は 26000 である。解析には AlSi10Mg 合金 の比熱 $\left(9 \times 10^{5} \mathrm{~J} \cdot \mathrm{g}^{-1} \mathrm{~K}^{-1}\right)^{27}$ と密度 $\left(2.67 \mathrm{~g} \cdot \mathrm{m}^{-3}\right)^{27}$ を用いた. ベースプレート（及び凝固部）の合金の熱伝導率として, $175 \mathrm{~W} \cdot \mathrm{m}^{-1} \mathrm{~K}^{-1}$ 27) を採用した。また，粉末層の熱伝導率は Wei $ら^{30)}$ の実測例から緻密体の $1 / 100$ とした。レーザ吸収率は, 波長 $1090 \mathrm{~nm}$ を持つ $\mathrm{Yb}$ レーザに対する AlSi10Mg 合金の測 定值の $0.6^{28)}$ を採用した．合金粉末の相対密度は $0.6^{29)}$ を用い た．本解析で用いたレーザ走查速度とレーザ出力はそれぞ れ $2 \mathrm{~m} / \mathrm{s}$ と $250 \mathrm{~W}$ である。本条件は，相対密度 $99 \%$ の造形体 を作製可能なものである Gaussian 分布に従う ${ }^{31}$ ことが知られているため，本解析では スポットサイズ $0.1 \mathrm{~mm}$ を直径とした Gaussian 分布に従って 熱流速を粉末層表面に与えた（Fig. 8 (b))。なお，本解析で は $0.04 \mathrm{~s}$ 程度を経過するとモデル内の温度分布は一様な定常 状態になることを確認している.

上記の条件下で粉末層表面に熱流速を付与後, レーザ照 射通過直後の $5 \times 10^{-5} \mathrm{~s}$ 経過した解析モデル内の温度分布を Fig. 9 (a) に示す。レーザ照射直下の材料温度（ベースプレー 卜部）は $3000^{\circ} \mathrm{C}$ 以上に達し，その温度は放射状に低下して いることがわかる。この解析を基に, 状態図（Fig. 2) から 読み取った AlSi10Mg 合金の液相温度である $600^{\circ} \mathrm{C} に$ 達した 領域を Fig. 9 (b) に示す。これはレーザ局所加熱により溶融 した領域であると考えられ，造形体にて観察される溶融池 （Fig. 3 (b)）に相当する. 本解析で再現した溶融池の深さは 約 $110 \mu \mathrm{m}$ と，実験で観察されたものよりもやや小さい。有 限要素解析は材料中の熱伝導を再現した温度分布であるた

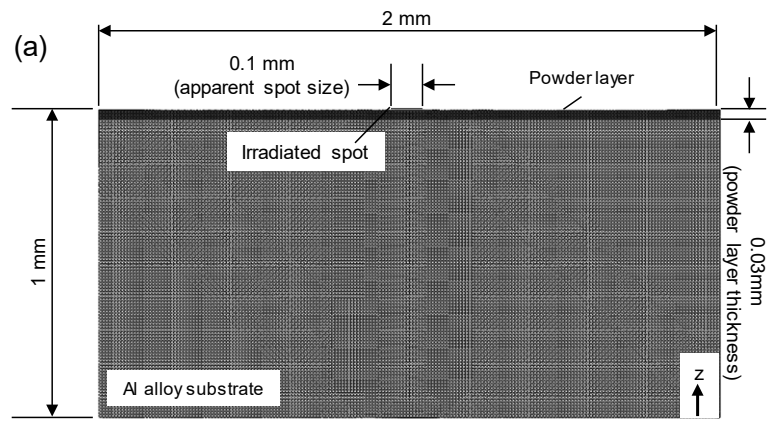

(b)

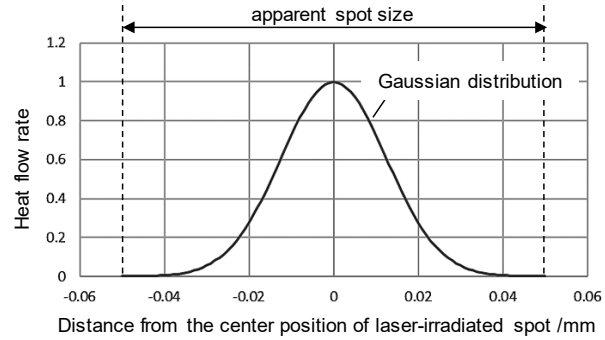

Fig. 8 (a) Two-dimensional finite element model and (b) laser intensity profiles for the circular Gaussian shape (apparent spot size: $100 \mu \mathrm{m})$ applied in the present study.

(a) laser-irradiated spot

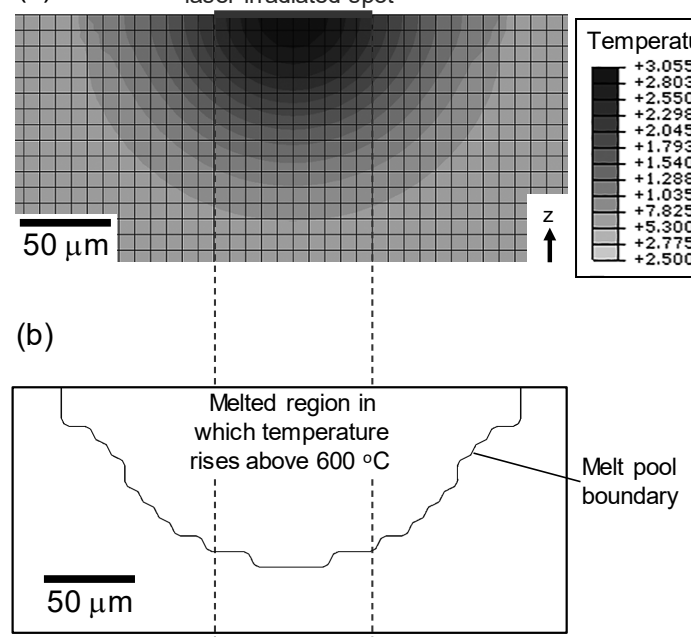

Fig. 9 (a) Calculated temperature distribution in the laser-irradiated (after the $5 \times 10^{-5} \mathrm{~s}$ ) and (b) a melted region in which temperature rises above $600^{\circ} \mathrm{C}$ (corresponding to liquidus temperature).

め，局所的な材料の気化 ${ }^{32)} に よ る$ 実際のレーザ照射表面の 変化などを考慮していない，したがって本解析は，アルミニ ウム合金造形体の溶融池形成に及ぼすレーザ照射による局所 的な材料の気化とそれに伴う溶融金属の対流 ${ }^{32)}$ の寄与を示 唆する。レーザ照射された粉末層直下のベースプレート部 の温度履歴を Fig. 10 に示す。レーザ照射により温度は局所 的に $4000^{\circ} \mathrm{C}$ 以上まで上昇するが，その後急激に低下し， $1 \times$ $10^{-3} \mathrm{~s}$ 後抒よそ $130^{\circ} \mathrm{C}$ 以下になる (Fig. 10 (a))。この温度履 歴を基にした液相温度と固相温度間の泠却速度（凝固速度） は，約 $2 \times 10^{6}{ }^{\circ} \mathrm{C} / \mathrm{s}$ であった（Fig. 10 (b))，以上のように，有 限要素解析を用いた各領域の温度履歴を基にレーザ積層造形 中の冷却速度や溶融池形状は予測できると考えられる。 

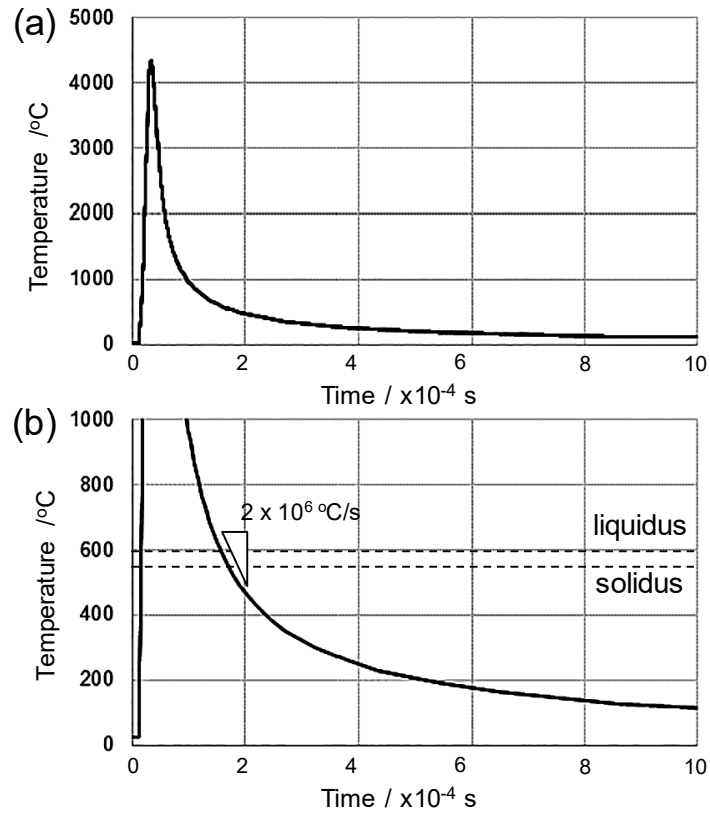

Fig. 10 Calculated temperature profile of the $\mathrm{Al}$ alloy substrate underneath the powder layer.

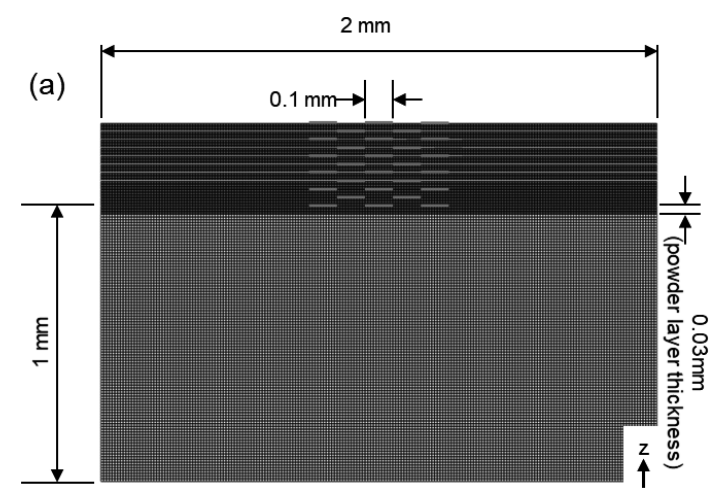

(b)

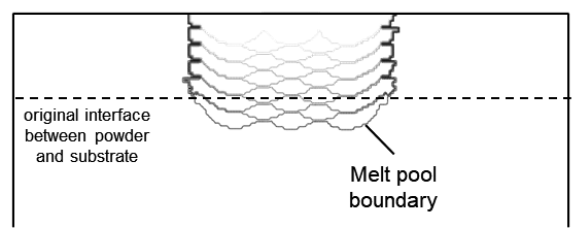

Fig. 11 (a) Two-dimensional finite element model for the repeated process of powder bed and laser irradiation (SLM process) used in this study and (b) the calculated melted regions in which temperature rises above $600^{\circ} \mathrm{C}$ (corresponding to liquidus temperature) by the repeat process.

本来の積層造形プロセスは粉末層上のレーザ照射の繰り返 しである。そのため，レーザ照射によって造形（凝固）され た領域はその上部に敷設される粉末層に照射されたレーザ 加熱の影響を受ける. 特に溶融池の深さは $100 \mu \mathrm{m}$ 以上であ るため, 厚さ $30 \mu \mathrm{m}$ の粉末層は複数回の溶融・凝固過程を経 て，造形体の組織を形成する。 そこで本解析は，複数回の レーザ走査と粉末層敷設を繰り返す造形プロセスを簡略的に 再現し（Fig. 11 (a)），レーザ後に凝固する領域の温度履歴に 着目し，温度分布の解析を行った。本解析条件はFig. 8 のモ
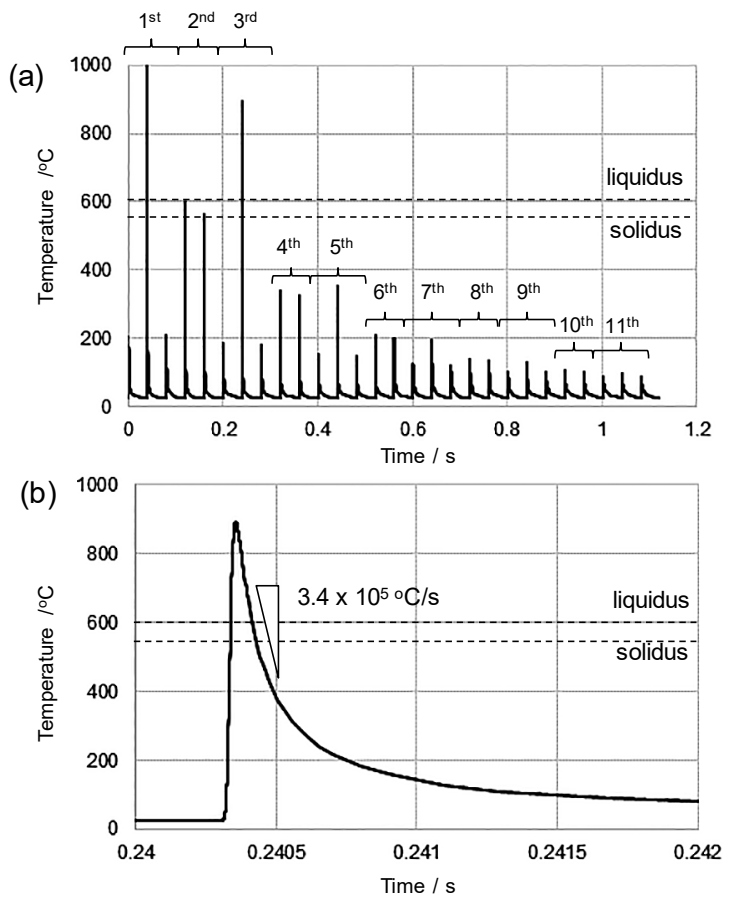

Fig. 12 Calculated temperature profile of the Al alloy substrate underneath the powder layer during the repeat process of powder bed and laser irradiation (SLM process).

デルと同じであり，隣り合うレーザ照射間隔（hatch distance） は $100 \mu \mathrm{m}$ とした。ただし，ベースプレートの寸法は今回の 解析モデルの寸法に比べて十分大きい. この効果は, 解析モ デルの周囲に等価な熱伝達条件を考慮することによって代 替させた。 具体的には, 解析モデルの側面と底面に $1 \mathrm{~mm} の$ 厚さをもった凝固部（熱伝導率 $1.75 \mathrm{~W} \cdot \mathrm{m}^{-1} \mathrm{~K}^{-1}$ ) の層がある と考え, これを $1.75 \mathrm{~W} \cdot \mathrm{m}^{-2} \mathrm{~K}^{-1}$ の熱伝達係数としてモデル化 した，雲囲気温度は $25^{\circ} \mathrm{C}$ とした，その解析を基に，各レー ザ照射によって $600^{\circ} \mathrm{C}$ に達した領域の境界線を描画した図を Fig. 11 (b)に示す. 溶融池の深さは上述した問題にて再現で きないが, 造形体特有のうろこ状の組織形態 (Fig. 3 (b)) を 再現できた。したがって, 状態図に基づいた液相線を考慮し, 有限要素解析を用いて温度履歴を再現することによって, レーザ積層造形プロセスにて形成する溶融池形状の予測が可 能であると考えられる. Fig. 12 に，本解析におけるレーザ照 射された粉末層直下のベースプレート部の温度履歴を示す.

Fig. 12 (a) 中に示す数字は粉末積層の回数を示す.このレー ザ出力・走査速度の条件下では, 4 回目以降の粉末層敷設と レーザ照射では液相と固相温度に達しないことがわかる。こ れは, 造形体の凝固組織が 3 層目の粉末層に照射されたレー ザによる加熱（溶融・凝固）によって形成することを示す. その温度履歴を詳細に解析した結果を, Fig. 12 (b)に示す. この冷却中における液相温度と固相温度間の冷却速度（凝 固速度）は，約 $3.4 \times 10^{5}{ }^{\circ} \mathrm{C} / \mathrm{s}$ であった。この值は, 以前より 計算されているアルミニウム合金の積層造形中の冷却速度 ${ }^{33}$ と比較的良い一致を示す。なお，4回目以降の粉末層敷設と レーザ照射において造形部は複数回加熱と冷却されており 
(Fig. 12 (a))，これらの温度履歴も造形体の組織を理解する 上で重要と考えられる．以上のような有限要素モデルを用い た熱伝導解析は積層造形プロセスに伴う温度履歴を定量的に 予測し，状態図を併用することによって造形体の特徴的な組 織形成の理解を加速させると考えられる.

\section{5 おわりに}

本解説では, レーザ積層造形技術に適用される代表的なア ルミニウム合金である $\mathrm{AlSi} 10 \mathrm{Mg}$ 合金を例に取り，熱力学計 算を基にした多元系状態図を用いて造形体の組織の特徴を紹 介した。造形体の組織はレーザ照射による局所溶融・急冷凝 固に伴う組織変化を基に理解できると考えられる．実験によ る測定が極めて困難である積層造形中の温度分布・履歴の予 測は有限要素解析が有用であり, 造形体の凝固組織を生み出 す冷却速度は約 $10^{5}{ }^{\circ} \mathrm{C} / \mathrm{s}$ と見積もることができた。 しかし， 本稿で紹介した現状の解析は予備的なものであり，局所的な 気化の影響，粉末と造形体（及びベースプレート）の物性の 違い, 合金の固体と液体の物性の違いとそれらの温度依存 性，粉末層のレーザ吸収率 ${ }^{34)}$ などを考慮できていない。これ らの因子を再現した解析が冷却速度や溶融池形状の精緻化に 不可欠である. 同時に, 近年発展著しい透過X線イメージ ングの高い空間・時間分解能 ${ }^{35)}$ やそれに伴う温度計測技術の 精緻化は直接解析に反映可能であり, 解析精度を著しく向上 させると期待される。今後，理論計算を援用した更なる実験 が造形体の組織形成の本質的理解だけでなく，積層造形技術 を利用した組織制御も含めた造形パラメー夕の最適化 要であると考えられる

\section{謝辞}

本解説で紹介した研究成果の一部は, 知の拠点あいち重点 プログラム（II 期）「革新的金型製造技術の開発とその産業 応用」及び (III 期)「積層造形技術の高度化と先進デザイン の融合による高機能部材の創製」の支援により行われたもの である. 詳細な組織解析は名古屋大学大学院生 小平寛久君, 劉牧霖君の尽力によるものである.ここに特記して謝意を示す.

\section{文献}

1) H. Kyogoku: J. Jpn. Soc. Precision Engineering, 82 (2017) 619-623.

2) H. Kyogoku, T. Ikeshoji: J. Jpn. Soc. Powder Powder Metallurgy, 66 (2019) 89-96.

3) Y. Koizumi, A. Chiba, N. Nomura, T. Nakano: Materia, 56 (2017) 686-692.

4) W. J. Sames, F. A. List, S. Pannala, R. R. Dehoff, S. S. Babu: International Materials Reviews, 61 (2016) 1-46.

5) D. Herzog, V. Seyda, E. Wycisk, C. Emmelmann: Acta Mater., 117 (2016) 371-392.

6) T. DebRoy, H. L. Wei, J. S. Zuback, T. Mukherjee, J. W. Elmer, J. O. Milewski, A. M. Beese, A. Wilson-Heid, A. De, W. Zhang: Prog. Mater. Sci., 92 (2018) 112-224.
7) N. Kanetake, M. Kobashi: J. Jpn Inst. Light Metals, 62 (2012) 112-134.

8) T. Kimura, T. Nakamoto: J. Jpn. Soc. Powder Powder Metallurgy, 61 (2014) 531-537.

9) E. O. Olakanmi, R. F. Cochrane, K. W. Dalgarno: Prog. Mater. Sci., 46 (2015) 401-477.

10) J. H. Martin, B. D. Yahata, J. M. Hundley, J. A. Mayer, T. A. Schaedler, T. M. Pollock: Nature, 546 (2017) 365-369.

11) I. Maskery, N. T. Aboulkhair, A. O. Aremu, C. J. Tuck, I. A. Ashcroft, R. D. Wildman, R. J. M. Hague: Mater. Sci. Eng. A, 670 (2016) 264-274.

12) Y. Amani, S. Dancette, P. Delroisse, A. Simar, E. Maire: Acta Mater., 159 (2018) 395-407.

13) D. S. J. Al-Saedi, S. H. Masood, M. Faizan-Ur-Rab, A. Alomarah, P. Ponnusamy: Mater. Des., 144 (2018) 32-44.

14) M.-S. Pham, C. Liu, I. Todd, J. Lertthanasarn: Nature, 565 (2019) 305-311.

15) N. Takata, H. Kodaira, K. Sekizawa, A. Suzuki, M. Kobashi: J. Jpn Inst. Light Metals, 67 (2017) 582-588.

16) N. Takata, H. Kodaira, K. Sekizawa, A. Suzuki, M. Kobashi: Mater. Sci. Eng. A, 704 (2017) 218-228.

17) N. Takata, H. Kodaira, A. Suzuki, M. Kobashi: Mater. Char., 143 (2018) 18-26.

18) M. Liu, N. Takata, A. Suzuki, M. Kobashi: Mater. Des., 157 (2018) 478-491.

19) M. Liu, N. Takata, A. Suzuki, M. Kobashi: J. Mater. Sci. Tech. (2019) in press.

20) CompuTherm LLC: CompuTherm Database User's Guide, pp. 1-11 (http://www.computherm.com/download/ Database2016_Manual.pdf).

21) N. T. Aboulkhair, I. Maskery, C. Tuck, I. Ashcroft, N. M. Everitt: Mater. Sci. Eng. A, 667 (2016) 139-146.

22) W. Kurz, D. J. Fisher: Fundamentals of Solidification (Trans Tech.) (1989) 117.

23) S.-H. Sun, K. Hagihara, T. Nakano: Mater. Des., 140 (2018) 307-316.

24) T. Maeshima, K. Oh-ishi: Heliyon, 5 (2019) e01186.

25) P. Bidare, I. Bitharas, R. M. Ward, M. M. Attallah, A. J. Moore: Acta Mater., 142 (2018) 107-120.

26) Y. Huang, L. J. Yang, X. Z. Du, Y. P. Yang: Int. J. Ther. Sci., 104 (2016) 146-157.

27) EOS GmbH - Electro Optical Systems, Material Data Sheet EOS Aluminum AlSi10Mg, (2014) (https://www.eos.info/ msolutions/material_parameter/download/Aluminium AlSi10Mg.pdf).

28) S. Liu, H. Zhu, G. Peng, J. Yin, X. Zeng: Mater. Des., 142 (2018) 319-328

29) K. Dai, L. Shaw: Acta Mater., 52 (2004) 69-80.

30) L. C. Wei, L. E. Ehrlich, M. J. Powell-Palm, C. Montgomery, J. Beuth, J. A. Malen: Addit. Manuf., 21 (2018) 201-208. 
31) T. T. Roehling, S. S. Q. Wu, S. A. Khairallah, J. D. Roehling, S. S. Soezeri, M. F. Crumb, M. J. Matthews: Acta Mater., 128 (2017) 197-206.

32) D. Dai, D. Gu: Mater. Des., 55 (2014) 482-491.

33) X. Ding, L. Wang: J. Manuf. Proc., 26 (2017) 280-289.

34) X. P. Li, G. Ji, Z. Chen, A. Addad, Y. Wu, H. W. Wang, J. Vleugels, J. V. Humbeeck, J. P. Kruth: Acta Mater., 129 (2017) 183-193.
35) A. A. Martin, N. P. Calta, S. A. Khairallah, J. Wang, P. J. Depond, A. Y. Fong, V. Thampy, G. M. Guss, A. M. Kiss, K. H. Stone, C. J. Tassone, J. N. Weker, M. F. Toney, T. Buuren, M. J. Matthews: Nature Comm., 10 (2019) 1987.

36) A. Suzuki, R. Nishida, N. Takata, M. Kobashi, M. Kato: Addit. Manuf., 28 (2019) 160-168. 